\title{
Spatial distribution and habitat use by early fish stages in a dammed river basin, Southern Brazil
}

\author{
Diego Azevedo Zoccal Garcia ${ }^{1,4}$, Alexandro Derly Augusto Costa ${ }^{1,4}$, \\ Fernanda Simões de Almeida ${ }^{2}$, Andréa Bialetzki ${ }^{3}$ \& Mário Luís Orsi ${ }^{4}$ \\ 1. Programa de Pós-Graduação em Ciências Biológicas, Universidade Estadual de Londrina, Londrina, Paraná, Brazil; \\ diegoazgarcia@hotmail.com, alexandrouenp@gmail.com \\ 2. Laboratório de Genética e Ecologia Animal, Universidade Estadual de Londrina, Londrina, Paraná, Brazil; \\ fernandasa@uel.br \\ 3. Laboratório de Ecologia de Ictioplâncton (NUPELIA), Universidade Estadual de Maringá, Maringá, Paraná, Brazil; \\ bialetzki@nupelia.uem.br \\ 4. Laboratório de Ecologia de Peixes e Invasões Biológicas, Universidade Estadual de Londrina, Rodovia Celso Garcia \\ Cid, PR 445, Km 380, Campus Universitário, Caixa Postal 10.011, 86057-970 Londrina, Paraná, Brazil; orsi@uel.br
}

$$
\text { Received 02-V-2017. Corrected 09-I-2018. Accepted 06-II-2018. }
$$

\begin{abstract}
Fish diversity loss is threatened by the construction of dams as they prevent the regular natural dispersal among populations. Thus, conservation of key riverine habitats for fish reproduction may be essential for the recruitment of new native species of fish. The present study aimed to identify key habitats for fish spawning and early development in the Paranapanema River basin, as well as to determine the taxonomic composition, reproductive and life-history strategy, and to report spatial distribution of eggs, larvae and juveniles. The importance of lagoons, tributaries, and sub-tributaries was evaluated in the Paranapanema River basin between October 2012 and March 2013. Eggs and larvae samples were collected at dawn and dusk with conical plankton nets $(0.5 \mathrm{~mm}$ mesh size), whereas juveniles were captured during the day with seine and sieve $(0.5 \mathrm{~cm}$ mesh size). A total of 547 eggs, 904 larvae and 1228 juveniles were captured. We observed that 2 larvae and 288 juveniles of non-migratory species, parental care, and equilibrium life-history strategy, predominated in lagoons and tributaries. On the other hand, 13 larvae and 60 juveniles of short migratory distance, no parental care, and periodic life-history strategy predominated in sub-tributaries. The highest densities of eggs were recorded in tributaries and sub-tributaries (Tukey's test, $\mathrm{P}=0.001$ and $\mathrm{P}=0.03$, respectively), and the highest densities of larvae were recorded for lagoons and tributaries $(\mathrm{P}=0.005$ and $\mathrm{P}=0.0001$, respectively). Captures of eggs and larvae were higher at night; while the highest catches per unit effort of juveniles were recorded for tributaries and sub-tributaries. Fish species that adopt different life-history strategies can use diverse types of habitats during the early stages. Lagoons, tributaries and sub-tributaries of the Paranapanema River play different roles in the reproductive success of fish fauna in a heavily modified basin. The preservation of spawning and nursery areas trapped between reservoirs is necessary for Neotropical fish species recruitment and survival. Rev. Biol. Trop. 66(2): 605-621. Epub 2018 June 01
\end{abstract}

Key words: conservation, ichthyoplankton, non-native species, migratory species, regulated rivers, South America, spawning sites.

The constant modification of rivers by anthropogenic activities is partly responsible for the loss of freshwater biodiversity (Nilsson, Reidy, Dynesius, \& Revenga, 2005). Climate change, river pollution, riparian vegetation removal, unsustainable use of land, and nonnative species introduction are among the threats that affect the environment, and have caused declines in the abundance of local freshwater species (Casatti, Ferreira, \& Carvalho, 2009; Vitule, Freire, \& Simberloff, 2009; Strayer \& Dudgeon, 2010; Vörösmarty et al., 2010; Santos, Ferreira, \& Esteves, 2015; Teresa, Casatti, \& Cianciaruso, 2015). The construction 
of dams instantly changes the physiography of a watershed and blocks upstream movements of fishes, whereas reservoirs impede downstream movements (Agostinho, Pelicice, Petry, Gomes, \& Júlio Jr., 2007a; Poff, Olden, Merritt, \& Pepin, 2007; Pelicice, Pompeu, \& Agostinho, 2015). Dams introduce changes in the physical and chemical water conditions, as well as in the quantity and quality of the different types of habitats, with direct effects on the composition of the ichthyofauna (Pelicice, Pompeu, \& Agostinho, 2015; Agostinho, Gomes, Santos, Ortega, \& Pelicice, 2016; Lima et al., 2016). Soon after the dam closure, there is an increase in richness and abundance of fish assemblages. However, with the reservoir aging, the abundance decreases and the diversity is smaller than before the dam closure (Agostinho, Gomes, \& Pelicice, 2007b; Agostinho et al., 2007a; Lima et al., 2016). Furthermore, high-value migratory species may be replaced by reservoir-adapted introduced species (Hoeinghaus et al., 2009).

The life-history strategies of freshwater fish vary temporally and spatially according to abiotic environmental parameters, food availability, and predation pressure (Winemiller, 1989; 1995). Therefore, populations of small-sized and generalist species increase, whereas large-sized and specialist species (e.g. migratory) decrease, or even disappear from the impounded area (Agostinho et al., 2007b; Agostinho et al., 2016). In addition, the control of water flow by dams alters the flood pulse dynamics and interferes the onset of fish reproduction (Agostinho, Gomes, Veríssimo, \& Okada, 2004; Agostinho et al., 2007b; Agostinho, Pelicice, \& Gomes, 2008).

Given the alterations promoted by dams, it is expected that government authorities or companies involved in decision making, contemplate mitigation procedures in rivers altered by reservoirs, for the protection of critical habitats for spawning and early development of fishes. The identification of environments in which reproductive activities occur, both upstream and downstream of dams, is essential for the implementation of conservation measures for freshwater fish fauna (Baumgartner et al., 2004; Orsi, 2010). Fish surveys focusing on the distribution of fish early life stages to identify key sites for reproduction and potential successful recruitment, were carried out in the basins of the Upper Paraná (Baumgartner et al., 2004; Bialetzki, Nakatani, Sanches, \& Baumgartner, 2005; Reynalte-Tataje, Nakatani, Fernandes, Agostinho, \& Bialetzki, 2011; Gogola, Sanches, Gubiani, \& Da Silva, 2013; Suzuki, Zambaldi, \& Pompeu, 2013; Da Silva et al., 2015), Uruguay (Reynalte-Tataje, Hermes-Silva, Silva, Bialetzki, \& ZaniboniFilho, 2008; Da Silva, Reynalte-Tataje, \& Zaniboni-Filho, 2012; Reynalte-Tataje et al., 2012a; Reynalte-Tataje, Zaniboni-Filho, Bialetzki, \& Agostinho, 2012b; Ávila-Simas, ReynalteTataje, \& Zaniboni-Filho, 2014), Tocantins (Melo, Pinto, Freitas, \& Marques, 2009), and São Francisco rivers (Melo \& Severi, 2010). Management actions should prioritize the identification and conservation areas with evidence of fish reproduction.

The Paranapanema River is a great tributary of the Paraná River. Its course is transformed in a system of cascading reservoirs and 11 hydroelectric dams were built directly on the main river channel. The three downstream impoundments in the system are Rosana (17 m height of dam), Taquaruçu (23 m height), and Capivara (60 $\mathrm{m}$ height) dams, with capacity to generate 354,525 , and $619 \mathrm{MW}$, respectively. Their reservoirs flooded areas of marginal lagoons and floodplain habitats. The impoundments does not influence directly tributaries located in the upper reaches of the reservoirs. Fish passages facilities are absents in the dams, which blocked the downstreamupstream movement of fish (Poff \& Hart, 2002; Makrakis et al., 2012). As a result, fish populations are disconnected by human infrastructure in the Lower Paranapanema River basin. Habitats within the dammed river (i.e. lagoons, tributaries, and sub-tributaries) may alter their suitability as spawning and recruitment sites (Hoffmann, Orsi, \& Shibatta, 2005; Orsi, 2010). 
The life history of fishes is related to remaining critical habitats adjacent to the reservoirs (Gogola et al., 2013; Suzuki et al., 2013; Barzotto, Sanches, Bialetzki, Orvati, \& Gomes, 2015; Da Silva et al., 2015). Migratory fish species spawn in tributaries and sub-tributaries located upstream in reservoirs, where higher abundance of eggs are found (Baumgartner et al., 2004; Makrakis et al., 2012; Suzuki et al., 2013; Da Silva et al., 2015). On the other hand, higher abundance of fish larvae is generally found in marginal lagoons after drifting downstream. Lagoons are natural nurseries and have adequate conditions for the development of the early stages of fish, i.e., low water speed, reduced predation pressure and availability of food (Bialetzki et al., 2005; Ziober, Bialetzki, Gomes, \& Kipper, 2007).

We tested the hypothesis that: (i) migratory fishes spawn in sub-tributaries, the larvae drift through tributaries and settle in lagoons for rearing to juveniles; (ii) non-migratory fishes spawn and rearing occurs in lagoons. To test these predictions, the present study aimed to identify key habitats for spawning and the early development within the dammed Lower Paranapanema River basin. In particular, to determine the taxonomic composition of larvae and juvenile fish, and report spatial distribution of eggs, larvae, and juveniles among the three main habitats, lagoons, tributaries and subtributaries in the upper areas of the reservoirs.

\section{MATERIAL AND METHODS}

Study area: The Paranapanema River hydrographic basin extends from the Southwest of the state of São Paulo (SP) to the North-Northwest of the state of Paraná (PR)

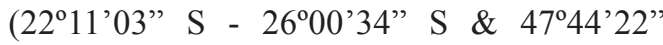
W - 53 $\left.09^{\prime} 44^{\prime \prime} \mathrm{W}\right)$. Its headwaters rise on the Atlantic Plateau, Serra de Paranapiacaba (SP), and the river runs through approximately 930 $\mathrm{km}$ to the West and drops $600 \mathrm{~m}$ until it flows into the Paraná River. The slope is considered an important feature of this river (Agostinho, Vazzoler, \& Thomaz, 1995). Its course was transformed into a cascade of dams, from downstream to upstream: Rosana, Taquaruçu, Capivara, Canoas I, Canoas II, Salto Grande, Ourinhos, Chavantes, Paranapanema, Piraju, and Jurumirim dams.

Due to the importance of lateral habitats for reproductive activities, were sampled: marginal lagoons, environments with low connectivity with the main river channel (Paranapanema River) and low water flow; tributaries, rivers that flow directly into the main river; and subtributaries, rivers that flow into tributaries (Fig. 1; Table 1). This study comprised a total of 11 samplings of undammed environments belonging to these three different habitats adjacent to the Rosana, Taquaruçu, and Capivara reservoirs. Rosana Reservoir was formed in 1987 and flooded $220 \mathrm{~km}^{2}$ with a length of $116 \mathrm{~km}$. In its upstream stretch, two lagoons connected to the river (Lagoon 1 and 2), and the mouths of tributaries Pirapozinho and Pirapó were sampled. Upstream of the Rosana Reservoir is the Taquaruçu Dam, which was built in 1989 and formed a reservoir of $80.1 \mathrm{~km}^{2}$ with a length of $80 \mathrm{~km}$. In this reservoir, the mouths of its main tributaries Centenário, Tenente, Capim, and Anhumas were sampled. Capivara Reservoir was formed in 1975 and is the largest of the Paranapanema River, accounting for $576 \mathrm{~km}^{2}$ and with a length of $115 \mathrm{~km}$. The river mouth of Vermelho, Capivara, and Tibagi tributaries shows a dendritic morphology. In this section, the sub-tributaries Congonhas, Apertados, and Taquara were sampled.

Sampling: Eggs, larvae, and juveniles were collected in a monthly basis, from October 2012 to March 2013, during the reproductive period of most fish species of the Upper Paraná River basin (Gogola et al., 2013; Da Silva et al., 2015). To evaluate the presence and abundance of eggs and larvae, diurnal (08:00) and nocturnal (20:00), samplings were carried out at each site in the limnetic zone of the river system by boat and manual sampling. Different sampling methods were used due to the difference in hydrodynamic environments (Nakatani et al., 2001). At the lagoons and tributaries, the nets were dragged by a boat at low speed 


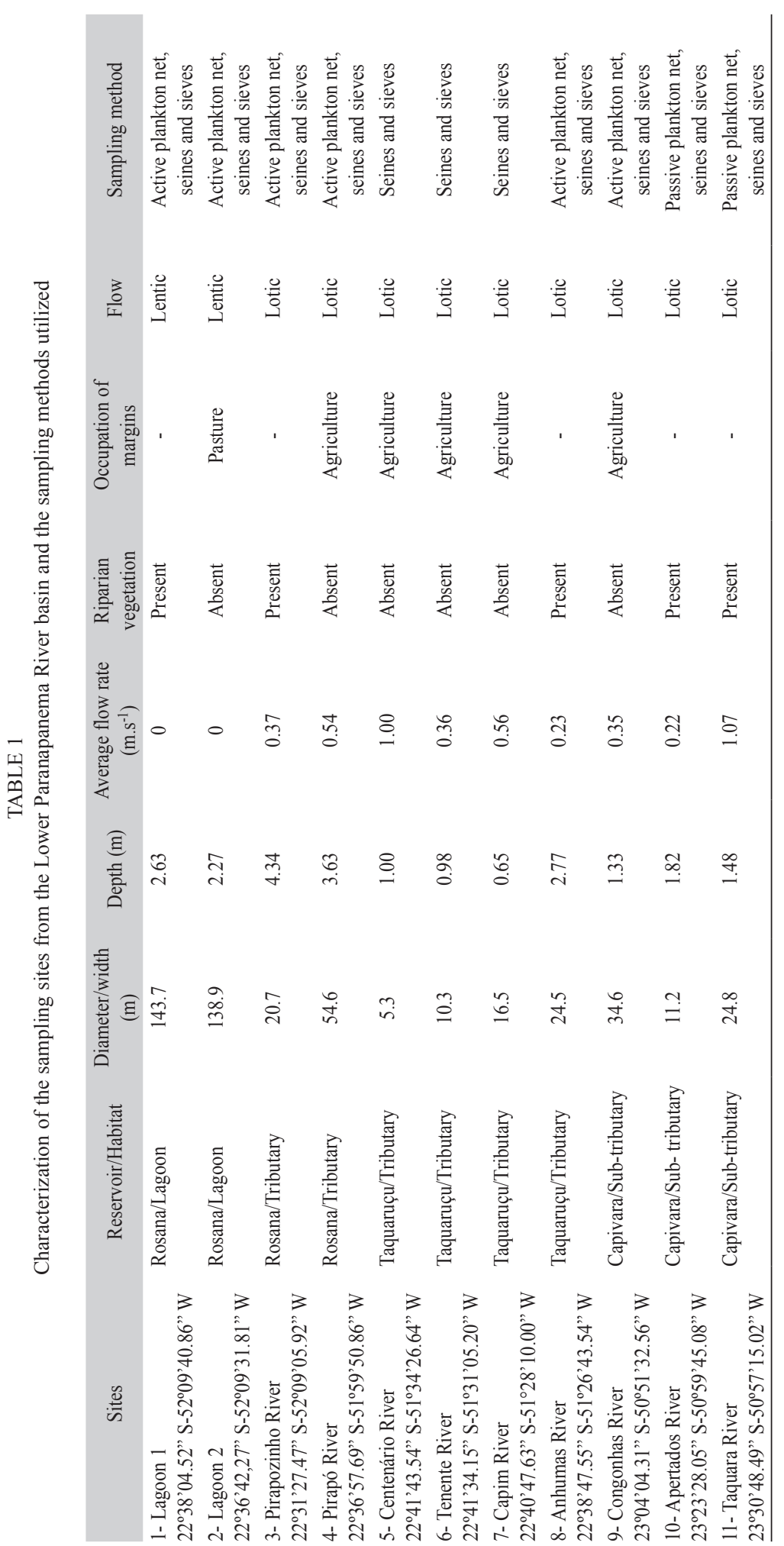




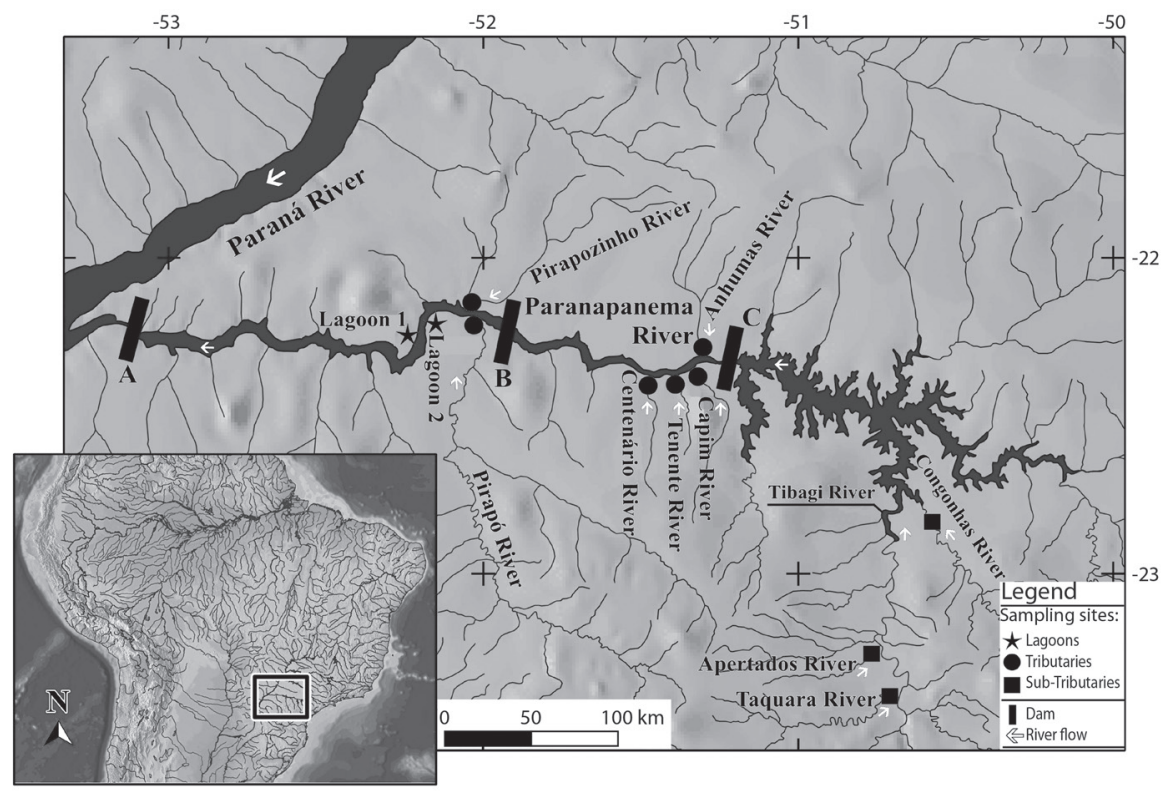

Fig. 1. Location of the sampling sites in the Lower Paranapanema River basin. Hydroelectric power plants: A- Rosana; B- Taquaruçu; C- Capivara.

$\left(\sim 4 \mathrm{~km} \cdot \mathrm{h}^{-1}\right)$ for 10 minutes (active method), whereas the nets were tied to a rope stretched between the two river banks at the sub-tributaries and submerged under the subsurface $(\sim 10$ $\mathrm{cm}$ depth) for 10 minutes (passive method) (Table 1). We used conical plankton nets of $0.5 \mathrm{~mm}$ mesh size with a mouth area of 0.1963 $\mathrm{m}^{2}$ equipped with a flow meter to obtain the filtered volume. Nine ichthyoplankton samples were taken in each sampling field monthly. For juveniles samplings, we used a seine $(6.0$ $\left.\mathrm{m}^{2}, 0.5 \mathrm{~cm} \mathrm{mesh}\right)$ and a sieve $\left(0.4 \mathrm{~m}^{2}, 0.5 \mathrm{~cm}\right.$ mesh) operated for one hour during daylight at each sampling site. This procedure was carried out close to the banks, under the vegetation, and along aquatic macrophyte beds, when present. Larvae and juveniles captured were anesthetized by immersion in water solution with clove oil, and all of the collected material was fixed with $4 \%$ buffered formaldehyde with calcium carbonate.

In the laboratory, samples were placed on a Bogorov-type plate and screened under a stereomicroscope. Eggs, larvae, and juveniles were separated from other materials and organisms. Larvae were considered the individuals that were in the period between hatching and the total fins formation (with rays) and scales (when present in the fish group), whereas juveniles were considered the individuals characterized by the complete fins formation and scales until sexual maturation (Nakatani et al., 2001). Larvae and juveniles were identified to the lowest possible taxonomic level (Nakatani et al., 2001) and grouped according to their reproductive strategy: non-migratory (NM), do not perform migration; short distance migratory (SDM), migrate less than $100 \mathrm{~km}$; long distance migratory (LDM), migrate over $100 \mathrm{~km}$; external fertilization (EF); internal fertilization (IF); parental care (PC); no parental care (NPC), parents do not take care of the offspring (Agostinho, Gomes, Suzuki, \& Júlio Jr., 2003). The life-history strategies of fish species were based according to Winemiller (1995): equilibrium (E), periodic $(\mathrm{P})$, opportunistic $(\mathrm{O})$, and intermediate between them, when the species presents factors associated to different life-history strategies. The damaged larvae and those identified above the order level, owing 
to their very early development stage, were assigned into the "unidentified" category.

The density of eggs and larvae was calculated for each site and standardized as ind./10 $\mathrm{m}^{3}$ of filtered water (Tanaka, 1973, modified by Nakatani et al., 2001). The catch per unit effort (CPUE) of juveniles was obtained by grouped areas of seines and sieves, and standardized for an area of $10 \mathrm{~m}^{2}$.

For the analysis of eggs and larvae densities per habitats (lagoons, tributaries, and subtributaries) and nictemeral variation (day and night), the data were previously transformed $(\log x+1)$ to meet the assumptions of the parametric analysis (normality and homogeneity of variance) (Peters, 1986). To detect possible spatial and nictemeral variation in egg and larval densities, a factorial analysis of variance (two-way ANOVA) was employed, with habitats and hours as independent factors. Variations in the capture per unit of effort of juveniles were analysed through one-way ANOVA, with habitats as independent factors. Tukey's test was then used as a post-hoc analysis to detect possible differences among levels. The significance level adopted was $\mathrm{P}<0.05$.

\section{RESULTS}

Taxonomic composition and reproductive/life-history strategies: During the study period, 547 eggs, 904 larvae, and 1228 juveniles were captured. Larvae and juveniles were identified to seven orders, 18 families, and 42 species. Among them, 12 were larvae and 38 juveniles (Table 2). The order Characiformes exhibited the highest number of taxa, followed by Siluriformes and Perciformes. The highest densities of larvae Characiformes were in the lagoons and sub-tributaries, Siluriformes in the lagoons and tributaries, whereas Perciformes was most abundant in the lagoons. With regard to larvae, the most abundant taxa were Plagioscion squamosissimus (Heckel, 1840), Parodontidae, Serrasalmus spp., Anostomidae, and Tatia neivai (Ihering, 1930).

Among the juveniles, the highest densities of Characiformes were in the sub-tributaries,
Siluriformes in the tributaries and sub-tributaries, and Perciformes in the sub-tributaries. The most abundant species were Geophagus brasiliensis (Quoy \& Gaimard, 1824), Piabarchus stramineus Eigenmann, 1908, Astyanax bockmanni Vari \& Castro, 2007, Piabina argentea Reinhardt, 1867, and Apareiodon affinis (Steindachner, 1879).

Non-native species were identified among larvae and juveniles. Specimens of Aphyocharax dentatus Eigenmann \& Kennedy, 1903, Hyphessobrycon eques (Steindachner, 1882), Serrasalmus marginatus Valenciennes, 1837, Loricariichthys platymetopon Isbrücker \& Nijssen, 1979, Pterygoplichthys ambrosettii (Holmberg, 1893), Auchenipterus osteomystax (Miranda Ribeiro, 1918), Trachelyopterus galeatus (Linnaeus, 1766), Brachyhypopomus spp., P. squamosissimus, Cichla kelberi Kullander \& Ferreira, 2006, Oreochromis niloticus (Linnaeus, 1758), and Catathyridium jenynsii (Günther, 1862) were captured. Non-native species accounted for approximately $38 \%$ of the larvae and $26 \%$ of the juveniles, and were sampled in all habitats.

According to the reproductive strategy, there was predominance of non-migratory species and parental care (40.47 \%) (Fig. 2A), mainly in lagoons and tributaries. Species that perform short migrations and no parental care was the second most adopted strategy (30.95 $\%$, which predominated in sub-tributaries. The long distance migratory species and no parental care corresponded to $4.94 \%$ of the species. According to the life-history strategy, there was predominance of periodic species (34.70\%), followed by equilibrium (26.54 \%), and intermediate opportunistic/periodic species (22.44 \%) (Fig. 2B).

Spatial distribution and nictemeral variation of eggs and larvae: The two-way ANOVA revealed differences between the distribution of eggs $(\mathrm{df}=2 ; \mathrm{F}=3.76 ; \mathrm{P}=0.03)$, larvae $(\mathrm{df}=2 ; \mathrm{F}=9.39 ; \mathrm{P}=0.0004)$ and juveniles $(\mathrm{df}=2 ; \mathrm{F}=3.34 ; \mathrm{P}=0.04)$. The highest densities of eggs were recorded for the tributaries and sub-tributaries during the 


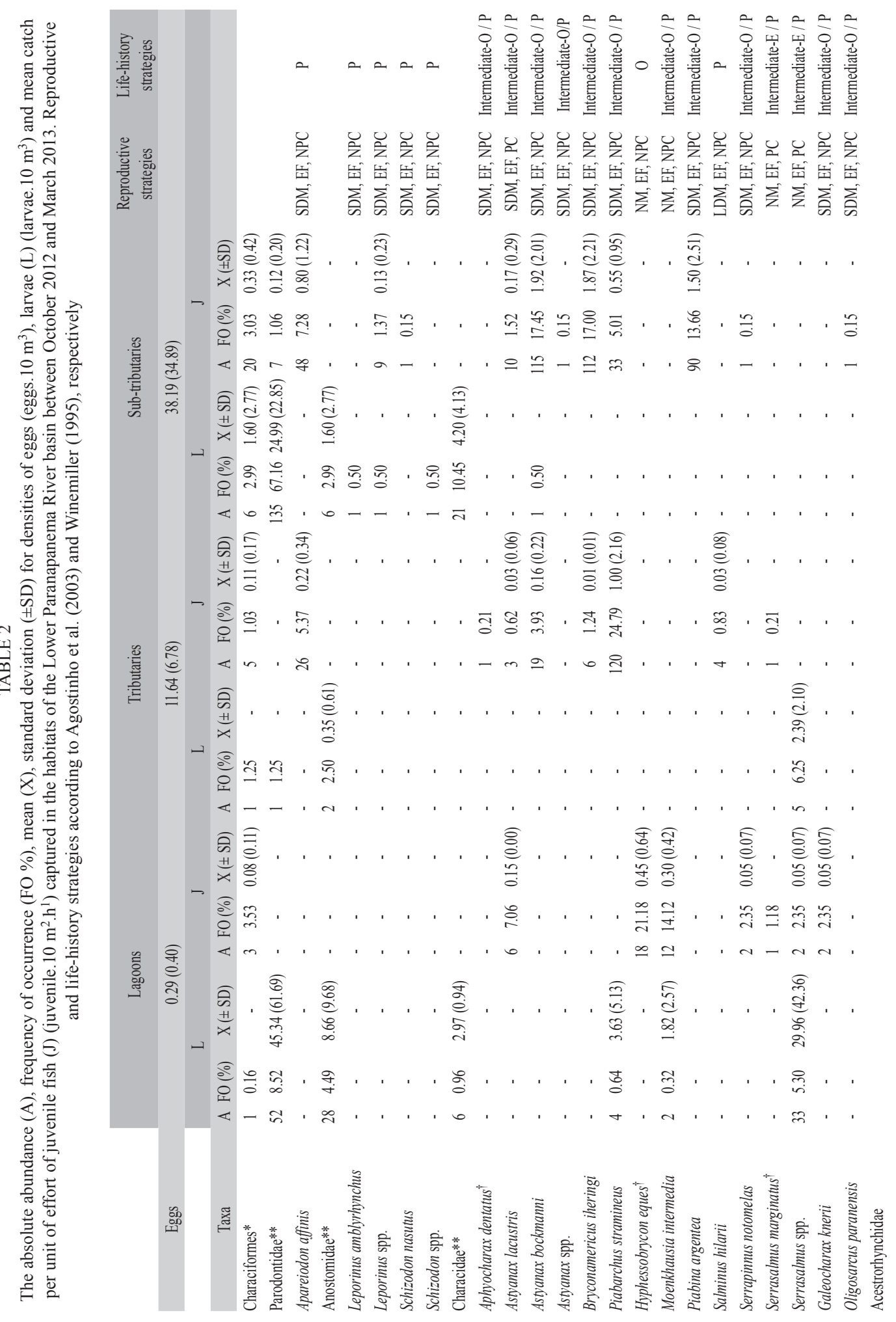

(c) (i) Rev. Biol. Trop. (Int. J. Trop. Biol. ISSN-0034-7744) Vol. 66(2): 605-621, June 2018 


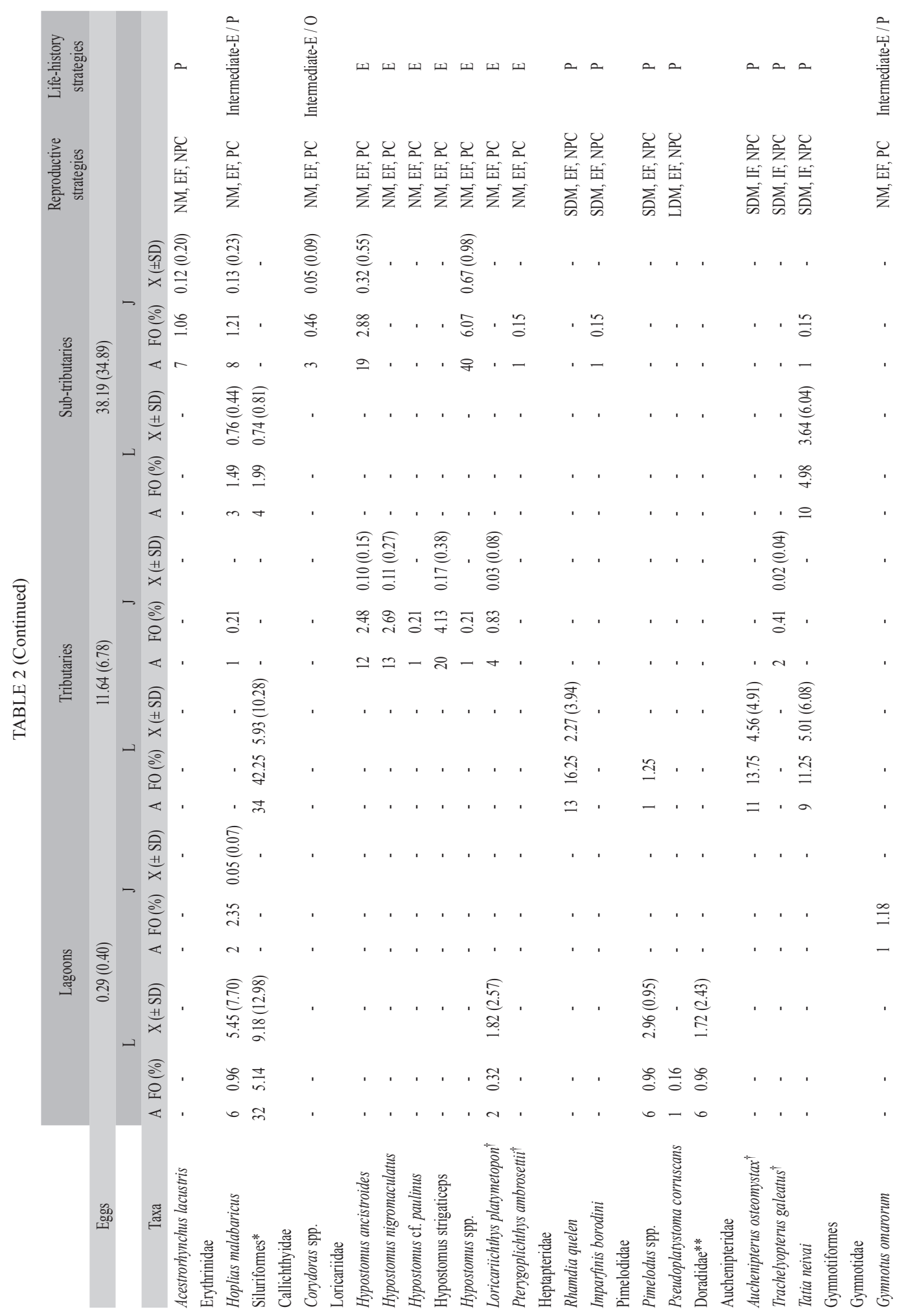




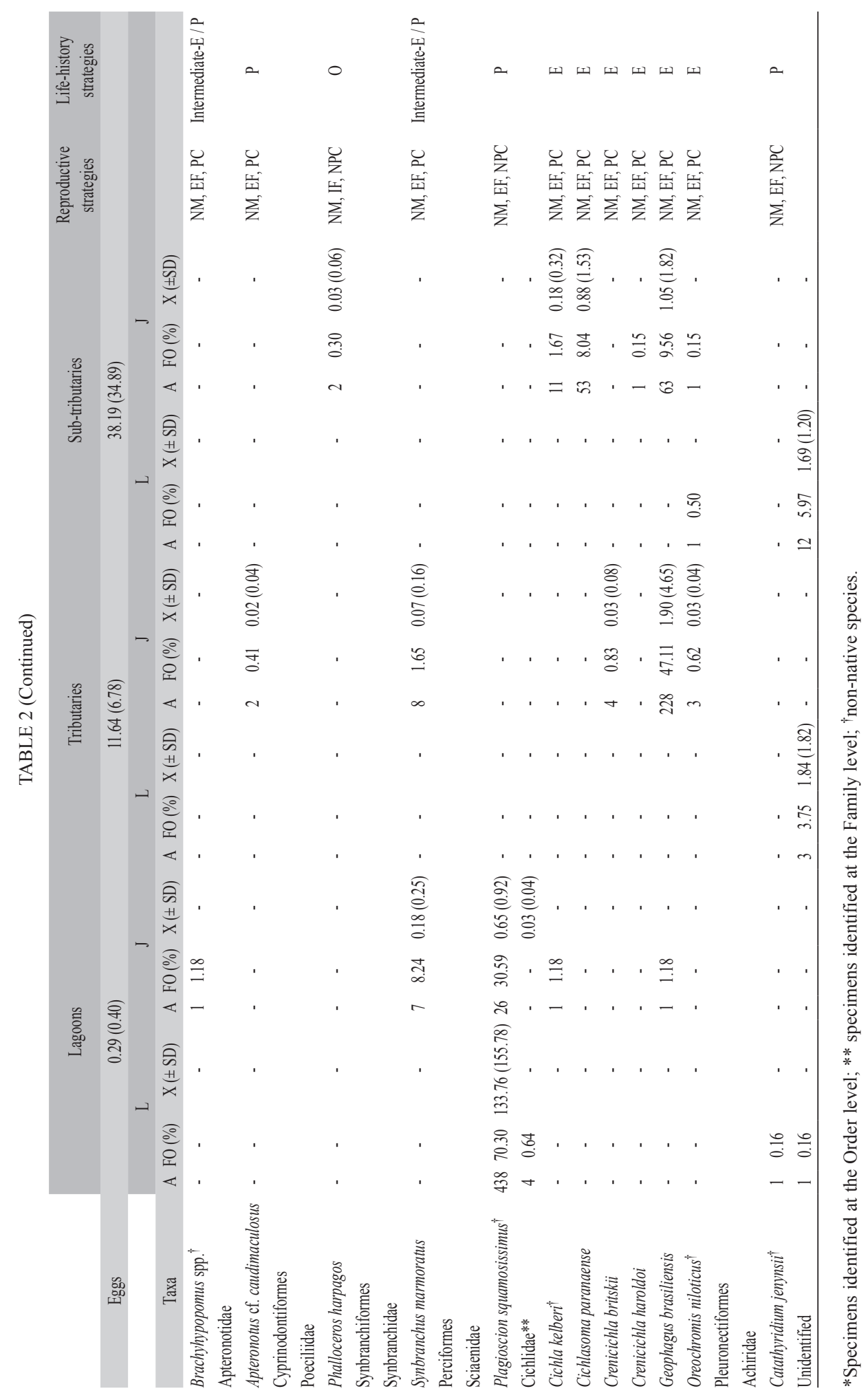

(c) (i) Rev. Biol. Trop. (Int. J. Trop. Biol. ISSN-0034-7744) Vol. 66(2): 605-621, June 2018 

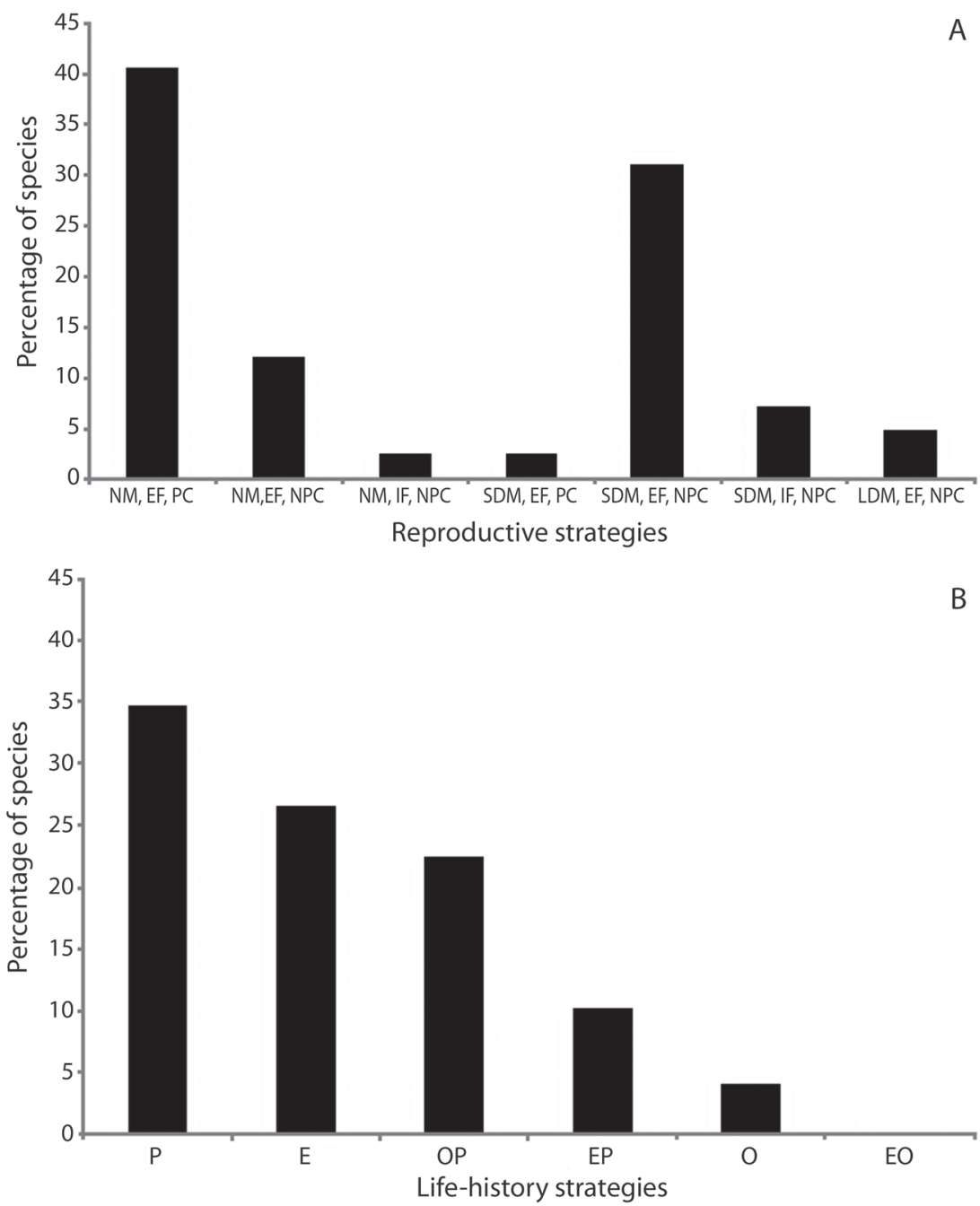

Fig. 2. Frequency of species for reproductive (A) and life-history (B) strategies of larvae and juvenile fish captured in the Lower Paranapanema River basin between October 2012 and March 2013. NM = non-migratory; SDM = short distance migratory; $\mathrm{LDM}=$ long distance migratory; $\mathrm{EF}=$ external fertilization; $\mathrm{IF}=$ internal fertilization; $\mathrm{PC}=$ parental care; $\mathrm{NPC}=$ no parental care; $\mathrm{P}=$ periodic $; \mathrm{E}=$ equilibrium; $\mathrm{O}=$ opportunistic $; \mathrm{OP}=$ intermediate opportunistic/periodic; $\mathrm{EP}=$ intermediate equilibrium/periodic; $\mathrm{EO}=$ intermediate equilibrium/opportunistic.

night (Tukey's test, $\mathrm{P}=0.001$ and $\mathrm{P}=0.03$, respectively) (Fig. 3A). The highest densities of larvae were recorded for the lagoons and tributaries, also during the night $(\mathrm{P}=0.005$ and $\mathrm{P}=0.0001$, respectively) (Fig. 3B).

The highest catches per unit effort of juveniles were recorded for tributaries and sub-tributaries. Lagoons and sub-tributaries differed from each other $(\mathrm{P}=0.04)$, whereas lagoons and tributaries did not differ from each other $(\mathrm{P}=0.22)$ (Fig. 4).

\section{DISCUSSION}

Larvae and juveniles of non-migratory species, with external fertilization and parental care, were sampled more often in lagoons and tributaries, where they complete their life 

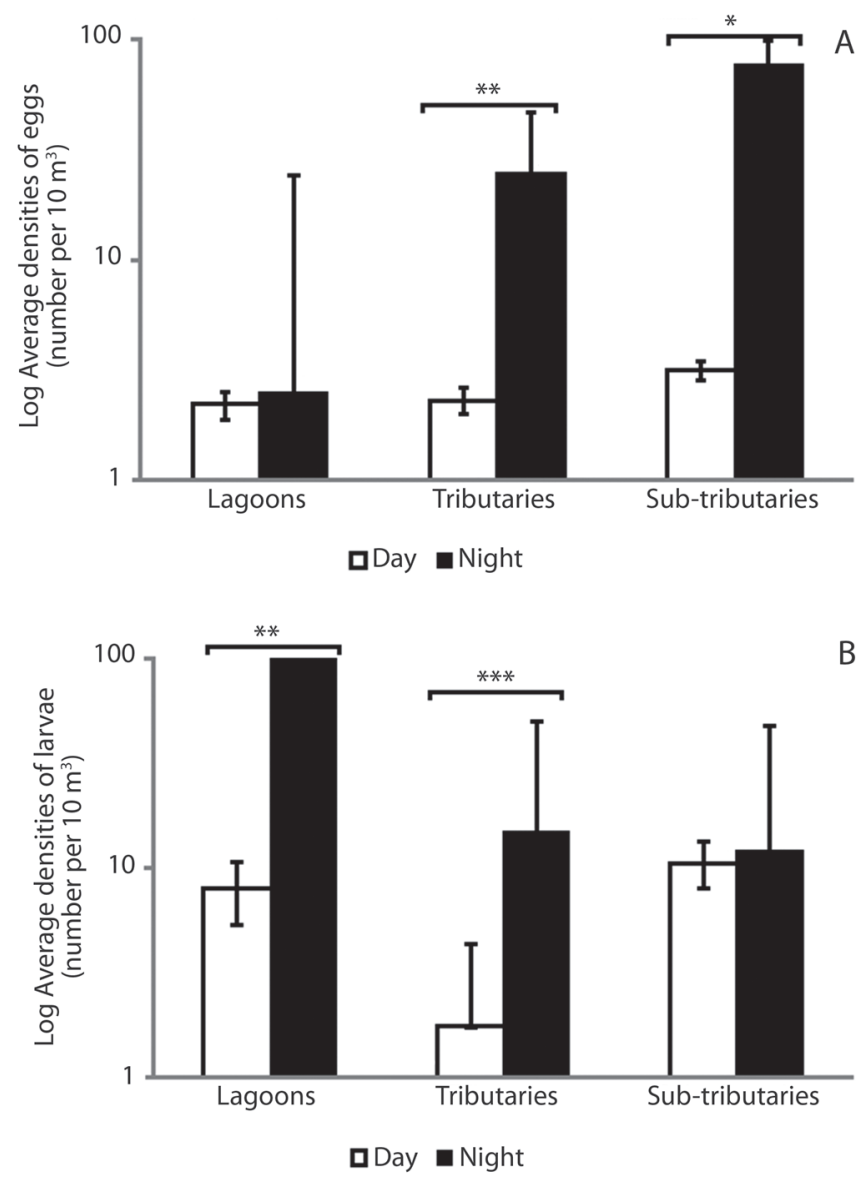

Fig. 3. Spatial distribution and nictemeral variation of eggs (A) and larvae fish (B) ( \pm standard error) in different habitats of the Lower Paranapanema River basin between October 2012 and March 2013. Asterisk indicated significant difference between day and night using the Tukey's test $(*=\mathrm{P}<0.05 ; * *=\mathrm{P}<0.005 ; * * *=\mathrm{P}<0.0001)$.

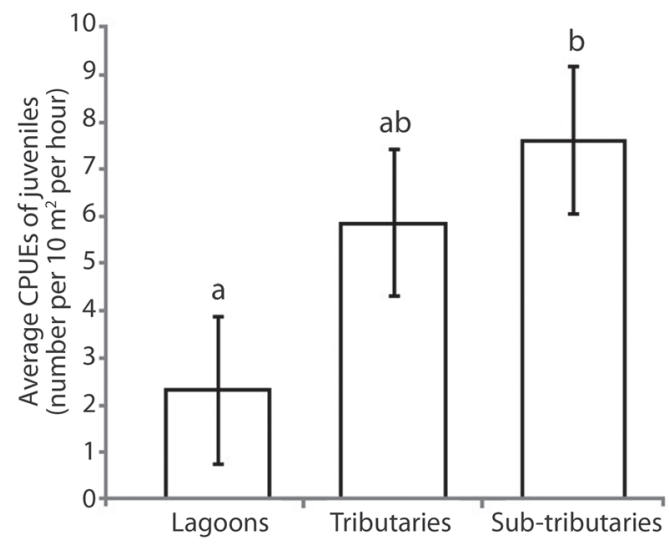

cycle in more lentic and shallow environments (Agostinho et al., 2003; Orsi, 2010). Such species exhibit equilibrium characteristics: repeated spawning, prolonged reproductive period, and large oocytes. Despite the small fecundity, they have high survivorship and small population fluctuations throughout the year

Fig. 4. Average catch per unit of effort of juvenile fish ( \pm standard error) in different habitats of the Lower Paranapanema River basin between October 2012 and March 2013. Different letters indicated significant differences between habitats using the Tukey's test at $5 \%$. 
(Winemiller, 1989; 1995). Thus, these fish species that inhabit habitat for reproduction may enhance offspring survival and recruitment success (Vazzoler, 1996; Nakatani et al., 2001).

In sub-tributaries, larvae and juveniles of short distance migratory species predominated, with external fertilization and no parental care. Among these are rheophilics: Apareiodon spp., Leporinus spp., and Schizodon spp., as well as $P$. argentea, Oligosarcus paranensis Menezes \& Géry, 1893, and Imparfinis borodini Mees \& Cala, 1989, which were exclusive to this habitat and indicated that the use of such environments is very important for the development of these taxa. The sub-tributaries play an appreciable role in the conservation of fish populations, providing reproduction sites for short distance migratory and rheophilic species. The greater occurrence of eggs in the subtributaries indicated that these areas represent effective spawning sites. Such species exhibit periodic and intermediate opportunistic/periodic characteristics. These fishes have seasonal spawning, short reproductive period, and small oocytes (Winemiller, 1989; 1995). These findings suggest that after spawning, juveniles of short distance migratory species, migrate upstream to the sub-tributaries motivated by flow conditions, and reside there during this stage of life. However, species that realize great migrations need different particular habitats for spawning and early development to the reproductive success and subsequent recruitment (Pompeu, Agostinho, \& Pelicice, 2012; Suzuki et al., 2013; Da Silva et al., 2015; Pelicice et al., 2015).

The low occurrence of species that perform long distance migrations is remarkable and may reflect the incidence of a small number of migratory breeders. Only two species: Pseudoplatystoma corruscans (Spix \& Agassiz, 1829), one larvae captured in the Lagoon 1, and Salminus hilarii Valenciennes, 1850, four juveniles in the Anhumas River were detected. In the Upper Paraná River basin, these species are rare and near-threatened with extinction (Abilhoa \& Duboc, 2004; Rosa \& Lima, 2008). Still, the sole detection of larvae and juveniles does not imply the presence of viable populations of long-distance migrants in the watershed (Agostinho et al., 2007b). These species require different habitats for the main phases of their life cycles, like spawning sites and nursery areas for development and growth. However, in many cases of basins strongly affected by damming, these critical habitats are fragmented by dams and long-distance migrants species are the most vulnerable and have reduced populations (Agostinho et al., 2008; Reynalte-Tataje et al., 2008; Pompeu et al., 2012; Pelicice et al., 2015).

The fish species with the highest density was $P$. squamosissimus and was exclusive to the lagoon habitat. In the larval stage, their diet consists of cladocerans, copepods, rotifers, algae, larvae of other fish species and perform cannibalism (Makrakis et al., 2005; Neves, Delariva, Guimarães, \& Sanches, 2015). Maturation in the first year of life, partial spawning, high fecundity (Vazzoler, 1996), and prolonged reproductive periods (Reynalte-Tataje et al., 2011) are responsible for their great reproductive success. In addition to these attributes, their eggs and larvae are pelagic, and present oil droplets that favor floating and ensure their wide dispersal capabilities (Bialetzki, Nakatani, Sanches, \& Baumgartner, 2004). These biological characteristics may be responsible for the high density of $P$. squamosissimus in lagoon habitat.

Plagioscion squamosissimus, native to the Amazon basin, was then introduced to the Paranapanema River basin to enhance populations in reservoirs (via fish stocking) (Ortega, Júlio Jr., Gomes, \& Agostinho, 2015). Early life stages of other 11 non-native fishes species have been detected as well in the Paranapanema River basin. This indicates that non-native fishes can potentially complete their life cycle in all habitats with a putative impact on the relative abundance and species richness of native organisms, including in the early stages (Latini \& Petrere Jr., 2004; Pelicice \& Agostinho, 2009; Petesse \& Petrere Jr., 2012).

Larvae fishes preferred lagoon habitat (Agostinho, Thomaz, Minte-Vera, \& 
Winemiller, 2000; Agostinho et al., 2007a; Ferrareze \& Nogueira, 2011). These nursery areas have low water flow and aquatic macrophytes, i.e., optimal conditions for the development and survival of individuals during early life stages, as well as for the organisms on which they feed (Ziober et al., 2007; ReynalteTataje et al., 2008). The fish larvae can feed on prey items inhabiting submerged macrophyte dominated microhabitats (Casatti, Mendes, \& Ferreira, 2003). Such environments may play both an important role in terms of abundant food resources and by providing shelter against potential predators during daytime (Agostinho et al., 2007b).

The higher densities of larvae in lagoons and tributaries at night are potentially associated with feeding strategies and predator avoidance during the day (Baumgartner, Nakatani, Makrakis, \& Baumgartner, 1997). This suggests the occurrence of lateral migration toward aquatic macrophyte banks (Nunn, Tewson, \& Cowx, 2012). Fish larvae may remain close to the benthos during the day and migrate to the surface during the night in search of food (Baumgartner et al., 1997). It can be also ascribable to the visual ability of the larvae. The most developed larvae have enhanced mobility that allows them to avoid motorized boats, thus preventing capture during the day, if that this is permitted by swimming performance and water transparency (Araújo-Lima, Silva, Petry, Oliveira, \& Moura, 2001).

Furthermore, the highest densities of eggs captured at night suggest that the spawning usually occurs during this period (Baumgartner et al., 1997; Baumgartner et al., 2004). This pattern was also observed in another study carried out in a tributary of the Middle Paranapanema River (Vianna \& Nogueira, 2008). Breeding event in tropical fishes is induced either by the reduction in light intensity (De Graaf, Born, Uddin, \& Huda, 1999), or by the increase in water temperature in the evening (Godoy, 1975). It is noteworthy that further studies aiming to characterize spawning sites in tributaries must conduct the samplings of eggs preferably at night.
These findings are important for the identification of critical habitats within basins with reservoirs in a cascade to determine breeding areas. Lagoons, tributaries, and sub-tributaries of the Paranapanema River basin play different roles in the reproductive success and conservation of remnant fish fauna in regulated rivers. Although the interruption of the long-distance migrants routes and disconnection of habitats by dams may reduce their recruitment, the preservation of fish spawning and nursery areas trapped between reservoirs is essential for Neotropical fish fauna maintenance.

\section{ACKNOWLEDGMENTS}

We thank Ângela Silva-Souza, Alexander Claro-García, Ângelo Agostinho, Fernando Pelicice, and Oscar Shibatta for reading our manuscript and giving suggestions for its improvement, and to the latter by the identification of juvenile fish. Aparecido de Souza, Edson Santana, and the LEPIB co-workers provided help during fieldwork. The project "Avaliação genética molecular e biológica das principais áreas de recrutamento nas porções média e baixa do rio Paranapanema com mecanismo de otimização dos programas de conservação e recuperação do estoque pesqueiro", funded by the Duke Energy International Geração Paranapanema (Process No3224/2012). We thank the anonymous reviewers for their help to improve the manuscript.

\section{RESUMEN}

Distribución espacial y uso de hábitat de peces en estadios tempranos de una represa del sur de Brasil. Los riesgos de pérdida de diversidad de peces aumentan con la construcción de represas, ya que impide la dispersión de individuos entre las poblaciones. Por lo tanto, la conservación del habitat ribereño clave para la reproducción de peces puede ser esencial para el reclutamiento de nuevos individuos de especies nativas. El presente estudio tiene como objetivo identificar hábitats clave para el desove y el desarrollo temprano de peces en la cuenca del río Paranapanema, así como determinar la composición taxonómica, la estrategia reproductiva y la historia de vida, y reportar la distribución espacial de huevos, larvas y juveniles. Se evaluó la importancia de lagunas, afluentes y subafluentes 
en la cuenca del río Paranapanema entre octubre de 2012 y marzo de 2013. Se recogieron muestras de huevos y larvas al amanecer y al atardecer con redes de plancton cónico (tamaño de malla de $0,5 \mathrm{~mm}$ ), mientras que los juveniles fueron capturados durante el día con redes de cerco y tamiz (tamaño de malla de $0,5 \mathrm{~cm}$ ). Se capturaron un total de 547 huevos, 904 larvas y 1228 juveniles. Como resultado fue observado que 2 larvas y 288 juveniles de especies no migratorias, cuidado parental y estrategia de vida de equilibrio son predominantes en lagunas y afluentes. Por otro lado, 13 larvas y 60 juveniles de espécies migratorias de corta distancia, sin cuidado parental y estrategia de vida periódica predominaron en subafluentes. Se registraron las densidades más altas de huevos para afluentes y subafluentes (Prueba de Tukey, $\mathrm{P}=0.001$ y $\mathrm{P}=0.03$, respectivamente), $\mathrm{y}$ se registraron las densidades más altas de larvas para las lagunas y afluentes $(\mathrm{P}=0.005$ y $\mathrm{P}=0.0001$, respectivamente). Las capturas de huevos y larvas eran más altas por la noche. Las mayores capturas por unidad de esfuerzo de juveniles se registraron para los afluentes y subafluentes. Las especies de peces que adoptan diferentes estrategias de historia de vida pueden utilizar diversos tipos de hábitats durante las primeras etapas. Lagunas, afluentes y subafluentes del río Paranapanema desempeñan diferentes papeles en el éxito reproductivo de la fauna de peces en una cuenca fuertemente modificada. La preservación de áreas de desove y cría atrapadas entre el embalse es necesaria para el reclutamiento de especies de peces neotropicales.

Palabras clave: conservación, ictioplancton, especies no nativas, especies migratorias, ríos regulados, América del Sur, sitios de desove.

\section{REFERENCES}

Abilhoa, V., \& Duboc, L. F. (2004). Peixes. In S. B. Mikich \& R. S. Bérnils (Eds.), Livro vermelho da fauna ameaçada no Estado do Paraná (pp. 581-682). Curitiba, Brasil: Instituto Ambiental do Paraná.

Agostinho, A. A., Vazzoler, A. E. A. M., \& Thomaz, S. M. (1995). The high river Paraná basin: limnological and ichthyological aspects. In J. G. Tundisi, C. E. M. Bicudo \& T. Matsumura-Tundisi (Eds.), Limnology in Brazil (pp. 59-103). Rio de Janeiro, Brasil: ABC/ SBL.

Agostinho, A. A., Thomaz, S. M., Minte-Vera, C. V., \& Winemiller, K. O. (2000). Biodiversity in the Paraná River Lateral. In B. Gopal, W. J. Junk \& J. A. Davis (Eds.), Biodiversity in wetlands: assessment, function and conservation (pp. 89-118). Leiden, The Netherlands: Backhuys Publishers.

Agostinho, A. A., Gomes, L. C., Suzuki, H. I., \& Júlio Jr., H. F. (2003). Migratory fishes of the Upper Paraná River Basin, Brazil. In J. Carolsfeld, B. Harvey, C. Ross, \& A. Baer (Eds.), Migratory Fishes of South America: biology, fisheries and conservation status (pp. 19-89). Victoria: World Fisheries Trust, The World Bank and The International Development Research Centre.

Agostinho, A. A., Gomes, L. C., Veríssimo, S., \& Okada, E. K. (2004). Flood regime, dam regulation and fish in the Upper Paraná River: effects on assemblage attributes, reproduction and recruitment. Reviews in Fish Biology and Fisheries, 14(1), 11-19. doi: 10.1007/ s11160-004-3551-y

Agostinho, A. A., Gomes, L. C., \& Pelicice, F. M. (2007b). Ecologia e manejo de recursos pesqueiros em reservatórios do Brasil. Maringá, Brasil: Eduem.

Agostinho, A. A., Pelicice, F. M., Petry, A. C., Gomes, L. C., \& Júlio Jr., H. F. (2007a). Fish diversity in the upper Paraná River basin: habitats, fisheries, management and conservation. Aquatic Ecosystem Health \& Management, 10(2), 174-186. doi: 0.1080/14634980701341719

Agostinho, A. A., Pelicice, F. M., \& Gomes, L. C. (2008). Dams and the fish fauna of the Neotropical region: impacts and the management related to diversity and fisheries. Brazilian Journal of Biology, 68(4), 11191132. doi: 10.1590/S1519-69842008000500019

Agostinho, A. A., Gomes, L. C., Santos, N. C. L., Ortega, J. C. G., \& Pelicice, F. M. (2016). Fish assemblages in Neotropical reservoirs: Colonization patterns, impacts and management. Fisheries Research, 173(1), 26-36. doi: 10.1016/j.fishres.2015.04.006

Araújo-Lima, C. A. R. M., Silva, V. V., Petry, P., Oliveira, E. C., \& Moura, S. M. L. (2001). Diel variation of larval fish abundance in the Amazon and Rio Negro. Brazilian Journal of Biology, 61(3), 357-362. doi: 10.1590/S1519-69842001000300003

Ávila-Simas, S., Reynalte-Tataje, D. A., \& Zaniboni-Filho, E. (2014). Pools and rapids as spawning and nursery areas for fish in a river stretch without floodplains. Neotropical Ichthyology, 12(3), 611-622. doi: 10.1590/1982-0224-20130116

Barzotto, E., Sanches, P. V., Bialetzki, A., Orvati, L., \& Gomes, L. C. (2015). Larvae of migratory fish (Teleostei: Ostariophysi) in the lotic remnant of the Paraná River in Brazil. Zoologia, 32(4), 270-280. doi: 10.1590/S1984-46702015000400002

Baumgartner, G., Nakatani, K., Makrakis, M. C., \& Baumgartner, M. S. T. (1997). Some aspects of ecology of fish larvae in the floodplain of the high Paraná River, Brazil. Revista Brasileira de Zoologia, 14(3), 551563. doi: 10.1590/S0101-81751997000300005

Baumgartner, G., Nakatani, K., Gomes, L. C., Bialetzki, A., Sanches, P. V., \& Makrakis, M. C. (2004). Identification of spawning sites as natural nurseries in the Upper Paraná River, Brazil. Environmental Biology of Fish, 71(2), 115-125. doi: 10.1007/ s10641-004-0098-Z 
Bialetzki, A., Nakatani, K., Sanches, P. V., \& Baumgartner, G. (2004). Eggs and larvae of the 'curvina' Plagioscion squamosissimus (Heckel, 1840) (Osteichthyes, Sciaenidae) in the Baía River, Mato Grosso do Sul State, Brazil. Journal of Plankton Research, 26(11), 1327-1336. doi: 10.1093/plankt/fbh123

Bialetzki, A., Nakatani, K., Sanches, P. V., \& Baumgartner, G. (2005). Larval fish assemblage in the Baía River (Mato Grosso do Sul State, Brazil): temporal and spatial patterns. Environmental Biology of Fishes, 73(37), 37-47. doi: 10.1007/s10641-004-3795-3

Casatti, L., Mendes, H. F., \& Ferreira, K. M. (2003). Aquatic macrophytes as feeding site for small fishes in the Rosana Reservoir, Paranapanema River, Southeastern Brazil. Brazilian Journal of Biology, 63(2), 213-222. doi: 10.1590/S1519-69842003000200006

Casatti, L., Ferreira, C. P., \& Carvalho, F. R. (2009) Grassdominated stream sites exhibit low fish species diversity and dominance by guppies: an assessment of two tropical pasture river basins. Hydrobiologia, 632(1), 273-283. doi: 10.1007/s10750-009-9849-y

Da Silva, P. A., Reynalte-Tataje, D. A., \& Zaniboni-Filho, E. (2012). Identification of fish nursery areas in a free tributary of an impoundment region, upper Uruguay River, Brazil. Neotropical Ichthyology, 10(2), 425438. doi: 10.1590/S1679-62252012005000012

Da Silva, P. S., Makrakis, M. C., Miranda, L. E., Makrakis, S., Assumpção, L., Paula, S., ... Marques, H. (2015). Importance of reservoir tributaries to spawning of migratory fish in the Upper Paraná River. River Research and Applications, 31(3), 313-322. doi: 10.1002/rra.2755

De Graaf, G. J., Born, A. F., Uddin, A. M. K., \& Huda, S. (1999). Larval fish movement in the River Lohajang, Tangail, Bangladesh. Fisheries Management and Ecology, 6(2), 109-120. doi: 10.1046/j.1365-2400.1999.00124.x

Ferrareze, M., \& Nogueira, M. G. (2011). Importance of lateral lagoons for the ichthyofauna in a large tropical reservoir. Brazilian Journal of Biology, 71(4), 807820. doi: 10.1590/S1519-69842011000500002

Godoy, M. P. (1975). Peixes do Brasil, subordem Characoidei, bacia do rio Mogi Guassu. v. 4. Piracicaba, Brasil: Editora Franciscana.

Gogola, T. M., Sanches, P. V., Gubiani, É. A., \& Da Silva, P. R. L. (2013). Spatial and temporal variations in fish larvae assemblages of Ilha Grande National Park, Brazil. Ecology of Freshwater Fish, 22(1), 95-105. doi: 10.1111/eff.12007

Hoeinghaus, D. J., Agostinho, A. A., Gomes, L. C., Pelicice, F. M., Okada, E. K., Latini, J. D., ... Winemiller, K. O. (2009). Effects of river impoundment on ecosystem services of large tropical rivers: embodied energy and market value of artisanal fisheries. Conservation Biology, 23(5), 1222-1231. doi: $10.1111 /$ j.1523-1739.2009.01248.x

Hoffmann, A. C., Orsi, M. L., \& Shibatta, O. A. (2005). Diversidade de peixes do reservatório da UHE Escola Engenharia Mackenzie (Capivara), Rio Paranapanema, bacia do alto rio Paraná, Brasil, e a importância dos grandes tributários na sua manutenção. Iheringia, Série Zoológica, 95(3), 319-325. doi: 10.1590/ S0073-47212005000300012

Latini, A. O., \& Petrere Jr., M. (2004) Reduction of a native fish fauna by alien species: an example from Brazilian freshwater tropical lakes. Fisheries Management and Ecology, 11(2), 71-79. doi: 10.1046/j.1365-2400.2003.00372.x

Lima, A. C., Agostinho, C. S., Sayanda, D., Pelicice, F. M., Soares, A. M. V. M., \& Monaghan, K. A. (2016). The rise and fall of fish diversity in a neotropical river after impoundment. Hydrobiologia, 763(1), 207-221. doi: $10.1007 / \mathrm{s} 10750-015-2377-\mathrm{z}$

Makrakis, M. C., Nakatani, K., Bialetzki, A., Sanches, P. V., Baumgartner, G., \& Gomes, L. C. (2005). Ontogenetic shifts in digestive tract morphologic and diet of fish larvae of the Itaipu Reservoir, Brazil. Environmental Biology of Fishes, 72(1), 99-107. doi: 10.1007/s10641-004-6596-9

Makrakis, M. C., Miranda, L. E., Makrakis, S., FontesJúnior, H. M., Morlis, W. G., Dias, J. H. P., \& Garcia J. O. (2012). Diversity in migratory patterns among Neotropical fishes in a highly regulated river basin. Journal of Fish Biology, 81(2), 866-881. doi: 10.1111/j.1095-8649.2012.03346.x

Melo, J. R. B., Pinto, M. D. S., Freitas, I. S., \& Marques, E. E. (2009). Variação temporal na abundância de ovos e larvas de peixes em diferentes biótopos da UHE Peixe Angical. In C. S. Agostinho, F. M. Pelicice, \& E. E. Marques (Eds.), Reservatório de Peixe Angical: bases ecológicas para o manejo da ictiofauna (pp. 121-130). São Carlos, Brasil: Rima.

Melo, Â. J. S., \& Severi, W. (2010). Abundância e distribuição espacial e sazonal do ictioplâncton no reservatório de Sobradinho, rio São Francisco, Bahia. In N. A. Moura, E. L. Araújo, M. C. BittencourtOliveira, R. M. M. Pimentel, \& U. P. Albuquerque (Eds.), Reservatórios do Nordeste do Brasil: Biodiversidade, Ecologia e Manejo (pp. 503-540). Bauru, Brasil: Nupeea.

Nakatani, K., Agostinho, A. A., Baumgartner, G., Bialetzki, A., Sanches, P. V., Makrakis, M. C., \& Pavanelli, C. S. (2001). Ovos e larvas de peixes de água doce: desenvolvimento e manual de identificação. Maringá, Brasil: Eduem.

Neves, M. P., Delariva, R. L., Guimarães, A. T. B., \& Sanches, P. V. (2015). Carnivory during ontogeny of the Plagioscion squamosissimus: a successful non-native fish in a lentic environment of the Upper 
Paraná River basin. PLoS ONE, 10(11), e0141651. doi: 10.1371/journal.pone.0141651

Nilsson, C., Reidy, C. A., Dynesius, M., \& Revenga, C. (2005). Fragmentation and flow regulation of the world's large river systems. Science, 308(5720), 405408. doi: 10.1126/science. 1107887

Nunn, A. D., Tewson, L. H., \& Cowx, I. G. (2012). The foraging ecology of larval and juvenile fishes. Reviews in Fish Biology Fisheries, 22(377), 377-408. doi: 10.1007/s11160-011-9240-8

Orsi, M. L. (2010). Estratégias reprodutivas de peixes da região média-baixa do rio Paranapanema, Reservatório de Capivara. São Paulo, Brasil: Blucher Acadêmico.

Ortega, J. C. G., Júlio Jr., H. F., Gomes, L. C., \& Agostinho, A. A. (2015). Fish farming as the main driver of fish introductions in Neotropical reservoirs. Hydrobiologia, 746(1), 147-158. doi: 10.1007/ s10750-014-2025-z

Pelicice, F. M., \& Agostinho, A. A. (2009) Fish fauna destructions after the introduction of a non-native predator (Cichla kelberi) in a Neotropical reservoir. Biological Invasions, 11(8), 1789-1801. doi: 10.1007/s10530-008-9358-3

Pelicice, F. M., Pompeu, P. S., \& Agostinho, A. A. (2015). Large reservoirs as ecological barriers to downstream movements of Neotropical migratory fish. Fish and Fisheries, 16(4), 697-715. doi: 10.1111/faf.12089

Peters, R. K. (1986). The role of prediction in limnology. Limnology and Oceanography, 31(5), 1143-1159. doi: 10.4319/lo.1986.31.5.1143

Petesse, M. L., \& Petrere Jr., M. (2012). Tendency towards homogenization in fish assemblages in the cascade reservoir system of the Tietê river basin, Brazil. Ecological Engineering, 48, 109-116. doi: 10.1016/j. ecoleng.2011.06.033

Poff, N. L., \& Hart, D. D. (2002). How dams vary and why it matters for the emerging science of dam removal. BioScience, 52(8), 659-668. doi: 10.1641/0006-3568(2002)052[0659:HDVAWI]2.0. $\mathrm{CO} ; 2$

Poff, N. L., Olden, J. D., Merritt, D. M., \& Pepin, D. M. (2007). Homogenization of regional river dynamics by dams and global biodiversity implications. Proceedings of the National Academy of Sciences of the United States of America, 104(14), 5732-5737. doi: 10.1073/pnas.0609812104

Pompeu, P. S., Agostinho, A. A., \& Pelicice, F. M. (2012). Existing and future challenges: the concept of successful fish passage in South America. River Research and Applications, 28(4), 504-512. doi: 10.1002/rra. 1557
Reynalte-Tataje, D. A., Hermes-Silva, S., Silva, P. A., Bialetzki, A., \& Zaniboni-Filho, E. (2008). Locais de crescimento de larvas de peixes na região do Alto Rio Uruguai (Brasil). In E. Zaniboni-Filho, \& A. P. O. Nuñer (Eds.), Reservatório de Itá: estudos ambientais, desenvolvimento de tecnologias de cultivo e conservação da ictiofauna (pp. 159-193). Florianópolis, Brasil: UFSC.

Reynalte-Tataje, D. A., Nakatani, K., Fernandes, R., Agostinho, A. A., \& Bialetzki, A. (2011). Temporal distribution of ichthyoplankton in the Ivinhema River (Mato Grosso do Sul State/Brazil): influence of environmental variables. Neotropical Ichthyology, 9(2), 427-436.

Reynalte-Tataje, D. A., Agostinho, A. A., Bialetzki, A., Hermes-Silva, S., Fernandes, R., \& Zaniboni-Filho, E. (2012a). Spatial and temporal variation of the ichthyoplankton in a subtropical river in Brazil. Environmental of Biology Fishes, 94(2), 403-419. doi: 10.1007/s10641-011-9955-3

Reynalte-Tataje, D. A., Zaniboni-Filho, E., Bialetzki, A., \& Agostinho, A. A. (2012b). Temporal variability of fish larvae assemblages: influence of natural and anthropogenic disturbances. Neotropical Ichthyology, 10(4), 837-846. doi: 10.1590/S1679-62252012000400017

Rosa, R. S., \& Lima, F. C. T. (2008). Os peixes brasileiros ameaçados de extinção. In: A. B. M. Machado, G. M. Drummond, \& A. P. Paglia (Eds.), Livro vermelho da fauna brasileira ameaçada de extinção (pp. 8-285). Belo Horizonte, Brasil: Fundação Biodiversitas.

Santos, F. B., Ferreira, F. C., \& Esteves, K. E. (2015). Assessing the importance of the riparian zone for stream fish communities in a sugarcane dominated landscape (Piracicaba River Basin, Southeast Brazil). Environmental Biology of Fishes, 98(8), 1895-1912. doi: 10.1007/s10641-015-0406-4

Strayer, D. L., \& Dudgeon, D. (2010). Freshwater biodiversity conservation: recent progress and future challenges. Journal of the North American Benthological Society, 29(1), 344-358. doi: 10.1899/08-171.1

Suzuki, F. M., Zambaldi, L. P., \& Pompeu, F. S. (2013). Mapping the critical habitats for migratory species of the upper Grande River region, Minas Gerais State, Brazil. Applied Ecology and Environmental Research, 11(4), 645-659.

Tanaka, S. (1973). Stock assessment by means of ichthyoplankton surveys. FAO Fisheries Technical Paper, $122,33-51$

Teresa, F. B., Casatti, L., \& Cianciaruso, M. V. (2015). Functional differentiation between fish assemblages from forested and deforested streams. Neotropical Ichthyology, 13(2), 361-370. doi: 10.1590/1982-0224-20130229 
Vazzoler, A. E. A. M. (1996). Biologia da reprodução de peixes teleósteos: teoria e prática. Maringá: Eduem.

Vianna, N. C., \& Nogueira, M. G. (2008). Ichthyoplankton and limnological factors in the Cinzas River - an alternative spawning site for fishes in the middle Paranapanema River basin, Brazil. Acta Limnologica Brasiliensia, 20(2), 139-151.

Vitule, J. R. S., Freire, C. A., \& Simberloff, D. (2009). Introduction of non-native freshwater fish can certainly be bad. Fish and Fisheries, 10(1), 98-108. doi: 10.1111/j.1467-2979.2008.00312.x

Vörösmarty, C. J., McIntyre, P. B., Gessner, M. O., Dudgeon, D., Prusevich, A., Green, P., Glidden, S., Bunn, S. E., Sullivan, S. A., Reidy Liermann, C., \& Davies, P. M. (2010). Global threats to human water security and river biodiversity. Nature, 467, 555-561. doi: 10.1038/nature09440

Ziober, S. R., Bialetzki, A., Gomes, L. C., \& Kipper, D. (2007) The importance of a marginal lagoon as a fish nursery in the upper Paraná River floodplain. Acta Limnologica Brasiliensia, 19(4), 369-381.

Winemiller, K. O. (1989). Patterns of variation in life history among South American fishes in seasonal environments. Oecologia, 81(2), 225-241. doi: 10.1007/ BF00379810

Winemiller, K. O. (1995). Aspects structurels et fonctionnels de la biodiversité des peuplements de poissons. Bulletin Français de la Pêche et de la Pisciculture, 337-338-339, 23-45. doi: 10.1051/kmae:1995007 